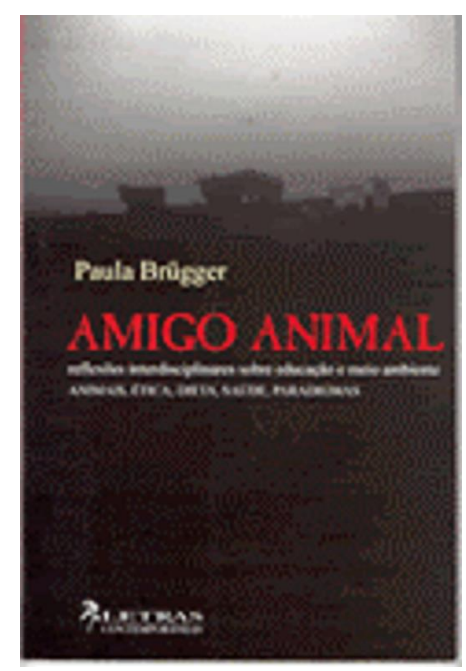

Capa divulgação do livro

\title{
Novo olhar sobre o animal
}

\section{Mariana Licéia Campos de Oliveira}

Licenciada em Letras, FALE/UFMG. Professora de Língua Espanhola, Língua Portuguesa e Literatura Brasileira. Participa do movimento ecológico, vegetariano e de proteção animal. Membro do Setor Verde do Programa A tela e o texto.

\section{BRÜGGER, Paula. Amigo animal. Florianópolis: Letras Contemporâneas Oficina Editorial Ltda., 2004.}

No livro Amigo animal, a professora Paula Brügger apresenta uma análise das relações que a sociedade estabelece com os animais não-humanos. Nessa análise, o animal - que na maioria dos discursos sociais é considerado como um "ser outro", marginalizado, quando não um simples objeto - recebe um olhar diferenciado, a partir de novos e transformadores paradigmas educacionais e ecológicos.

"É fácil viver de olhos fechados, sem compreender o que se vê"(1), afirma uma das epígrafes que abrem o livro. É sobre essa cegueira e esse comodismo humanos que Brügger vai discorrer, ao descrever o violento tratamento dado pela humanidade aos animais urbanos, àqueles que são usados como alimento ou àqueles que são vítimas da experimentação no ensino e na pesquisa. 
Vivemos em uma sociedade que dita padrões absurdos de comportamento, como o consumismo desenfreado, a valorização do ter mais do que o ser, e em que se acredita na supremacia absoluta do homem sobre os outros seres da natureza, o que faz com que os animais sejam ignorados ou usados para benefício humano, sem nenhuma atenção às suas necessidades mais básicas. Para analisar a condição dos animais sob uma nova ótica, Brügger dialoga com Fritjof Capra - autor de A teia da vida, um livro fundamental para quem quiser estudar mais o assunto e mostra que, para os animais serem vistos verdadeiramente como amigos, é necessário romper com a idéia tradicional de meio ambiente e adotar uma postura ecológica ou sistêmica. A visão tradicional de meio ambiente é aquela que considera que este é um lugar exterior a nós, nos induzindo, assim, a pensar que não fazemos parte dele e que podemos dominar os outros animais e os demais seres da natureza.

O pensamento ecológico é colocado no livro como a alternativa para reverter o processo de degradação do meio ambiente, que é também um processo de autodestruição provocado pelo antropocentrismo. Essa nova concepção de mundo considera que "as diversas formas de vida têm valor em si, independentemente da sua utilidade para os seres humanos"(2) e todos os seres vivos e os problemas que vivemos não podem ser entendidos isoladamente, porque estão interligados e são interdependentes.

A partir desse pensamento sistêmico, Brügger descortina a triste realidade dos animais urbanos: animais são brinquedos, presentes, meios de diversão? E o que dizer do comércio dessas vidas e do abandono que faz crescer a população de animais nas ruas e, consequentemente, seu sofrimento?

Ao falar dos animais usados como alimento, a autora mostra a estreita relação dessa dieta com vários problemas: doenças, sofrimento dos animais, injustiças sociais e destruição dos recursos naturais e da biodiversidade. Chama-nos, assim, a atenção para uma cadeia de destruição absurda e injustificável sob o ponto de vista ético, moral e educacional.

O terceiro tema discutido pela autora é a utilização de animais para pesquisa e ensino que, vista por muitos como um "mal necessário", reflete, mais uma vez, o antropocentrismo que marca nossa cultura e cultiva a violência. Brügger mostra que os gritos dos animais não são ouvidos e que qualquer problema científico, por mais banal que seja, é considerado mais importante que as vidas dos animais. A autora dialoga, assim, com o filósofo Peter singer e outros teóricos contemporâneos que discutem os direitos dos animais. 
Brügger analisa diversas implicações da vivisseç̧ão - uso de animais vivos no ensino e na pesquisa - e mostra que tais práticas são extremamente reducionistas e que perpetuam visões de doença e saúde também reducionistas. Ela defende, assim, que pratiquemos um consumo responsável, boicotando empresas que testam seus produtos em animais, e que não silenciemos diante do horror e das atrocidades que ainda são praticados nos laboratórios do século XXI.

Dessa forma, o leitor de Amigo animal é convidado a pensar na problemática ambiental por um viés não-fragmentário, já que, por mais que a humanidade insista em não enxergar sua natureza, somos apenas parte de um todo maior. A leitura do livro nos permite refletir sobre paradigmas ultrapassados e sobre as visões de mundo a eles subjacentes, estimulando a construção de valores que promovam um novo pensamento crítico e efetivas mudanças nas relações do homem com seu entorno, considerando que "há soluções para os principais problemas de nosso tempo, algumas delas até mesmo simples. Mas requerem uma mudança radical em nossas percepções, no nosso pensamento e nos nossos valores."(3) 